\title{
EFEKTIVITAS KONSUMSI TABLET FE DITAMBAH JUS BAYAM HIJAU DAN MADU TERHADAP PENINGKATAN KADAR HB IBU HAMIL
}

\author{
Novi Wulan Sari ${ }^{1)}$, Sri Linda Afriana ${ }^{2)}$ \\ Prodi Kebidanan, STIKes Fort De Kock \\ noviwulansari27@gmail.com, sl_afriana@yahoo.com
}

\begin{abstract}
ABSTRAK
Salah satu dampak dari kekurangan gizi pada saat hamil yaitu anemia. Berdasarkan hasil survey awal pada 7 dari 10 orang ibu mengalami anemia. Tujuan penelitian ini untuk mengetahui Efektivitas Konsumsi Tablet Fe Ditambah Jus Bayam Hijau Dan Madu Terhadap Peningkatan Kadar Hb Ibu Hamil.Jenis penelitian eksperimen, desain penelitian pretest and posttestwith controlgroup. Penelitian ini dilakukan di Wilayah Kerja Puskemas Rantau Panjang Kabupaten Merangin pada bulan Mei 2018. Populasi seluruh ibu hamil TM II-III yang mengalami anemia dengan jumlah sampel 16 orang dengan teknik purposive sampling. Data di analisa secara univariat dan bivariat dengan uji T-Test Dependent. Hasil uji statistik terdapat Efektivitas Konsumsi Tablet Fe Ditambah Jus Bayam Hijau Dan Madu Terhadap Peningkatan Kadar Hb Ibu Hamil (p value $=0,000$ ) dan terdapat perbedaan kadar Hb ibu hamil pada kelompok intervensi dan kelompok kontrol (p value=0,012). Kesimpulan terdapat Efektivitas Konsumsi Tablet Fe Ditambah Jus Bayam Hijau Dan Madu Terhadap Peningkatan Kadar Hb Ibu Hamil. Untuk itu diharapkan dengan adanya penelitian ini dapat membantu ibu hamil mencari solusi untuk meningkatkan kadar Hb agar terhindar dari anemia
\end{abstract}

Kata Kunci : Tablet Fe, Bayam Hijau dan Madu, Anemia

\section{EFFECTIVENESS OF FE TABLETS CONSUMPTION WITH GREEN SPINACH JUICE AND HONEY TO INCREASE HB LEVELS OF PREGNANT MOTHER}

\begin{abstract}
One of the effects of malnutrition during pregnancy is anemia. Based on a preliminary research results, it can be seen that 7 from 10 of mothers were anemia. The purpose of this study is to determine the effectiveness of $\mathrm{Fe}$ tablet consumption with green spinach juiceand honey in increasing $\mathrm{Hb}$ level of pregnant mother.The type of this research was experimental research, pretest and posttestwith control group design. The research was conducted in Community Health Center of Rantau Panjang Merangin on May 2018. All pregnant women TM II-III who suffer from anemia were the population of this research. Then, they were 16 with purposive sampling technique. Data were analyzed univariate and bivariate with test T-Test Dependent. The mean result before Furthermore, the result of statistical test was seen that it is effective to consume the Fe tablet with green spinach juice and honey in increasing $\mathrm{Hb}$ level of pregnant mother with $\mathrm{p}$ value $=0,000$.Then, there is difference of pregnant women $\mathrm{Hb}$ level in intervention group and control group $p$ value $=0.012$. In conclusion, there is affectivity of consumption Fe tablet with green spinach juice and honey to increase Hb Level of pregnant mother. It is expected that this research may help the pregnant women to find a solution to increase their Hb levels to avoid anemia.
\end{abstract}

Keywords: Fe Tablet, Green Spinach and Honey, Anemia 


\section{PENDAHULUAN}

Anemia adalah sejenis penyakit yang disebabkan oleh kurangnya hemoglobin atau butir-butir darah merah pada tubuh. Darah normal terdiri dari 40-45 \% butirbutir darah merah dan sekitar 55-60\% plasma darah. Dari setiap 100 mililiter darah biasanya terdapat kurang lebih 12,5 sampai 6 hemoglobin. Di dalam setiap satu milimeter kubik darah terdapat 4.500.000 sampai 5.500.000 sel-sel darah merah, kalau darah seseorang kurang dari jumlah darah yang terendah maka seseorang itu tergolong anemia (Maria, 2008).

Wanita hamil dikatakan mengidap penyakit anemia jika kadar hemoglobin $\mathrm{Hb}$ atau darah merahnya kurang dari 10 gram\%. Penyakit ini disebut anemia berat. Jika hemoglobinnya kurang dari 6 gram\% disebut dengan anemia gravis. Jumlah hemoglobin normal wanita hamil adalah 12-15 gram\% dan hemotokritnya adalah 35-54\% (Rahmawati, 2011).

Kekurangan zat besi dapat menimbulkan gangguan atau hambatan pada pertumbuhan janin baik sel tubuh maupun sel otak. Selain itu anemia defesiensi besi juga dapat mengakibatkan kecatatan bawaan, abortus, BBLR, anemia pada bayi yang dilahirkan bahkan sampai kematian janin di dalam kandungan. Hal ini dapat menyebabkan morbilitas dan mortalitas ibu dan kematian perinatal menjadi tinggi. Pada ibu anemia morbiditas dan mortalitas tinggi kemungkinan melahirkan bayi BBLR dan prematur juga sangat tinggi sehingga ibu hamil di anjurkan mengkonsumsi makanan yang mengandung zat besi (Sukarni dan Margareth, 2013).

Kebutuhan zat besi pada ibu hamil yaitu rata-rata mendekati $800 \mathrm{mg}$. Kebutuhan ini terdiri dari sekitar 300 mg diperlukan untuk janin dan plasenta serta $500 \mathrm{mg}$ lagi digunakan untuk meningkatkan masa hemoglobin maternal. Zat besi tersebut kurang lebih $200 \mathrm{mg}$ akan disekresikan lewat usus, urine dan kulit. Makanan ibu hamil setiap 100 kalori akan menghasilkan 8-10 $\mathrm{mg}$ zat besi. Perhitungan makan 3 kali dengan 2500 kalori akan menghasilkan sekitar 25-30 mg zat besi perhari. Selama kehamilan dengan perhitungan 228 hari, ibu hamil akan menghasilkan $100 \mathrm{mg}$ sehingga kebutuhan zat besi masih kekurangan untuk wanita hamil (Sukarni \& Margareth, 2013).

Anemia pada populasi ibu hamil menurut kriteria yang ditentukan WHO dan pedoman Kemenkes, yakni sebesar $37,1 \%$. Hal ini menunjukkan angka tersebut mendekati masalah kesehatan masyarakat berat (severe public health problem) dengan batas prevalensi anemia lebih dari 40\% (Riskesdas, 2013).

Bayam adalah sayuran yang memiliki gizi lengkap bagi penderita anemia. Bayam juga mengandung vitamin $\mathrm{C}$ yang cukup tinggi. Vitamin $\mathrm{C}$ memiliki peranan penting dalam penyerapan zat besi, sehingga zat besi yang ada dapat dimanfaatkan secara optimal (Lanny Lingga, 2010).

Bayam sebaiknya dikombinasikan dengan madu karena madu membantu permbentukan darah.Madu menyediakan banyak energi yang dibutuhkan tubuh untuk pembentukan darah. Lebih jauh lagi, ia juga membantu pembersihan darah. Madu berpengaruh positif dalam mengatur dan membantu peredaran darah (Aden R, 2010).

Berdasarkan uraian diatas peneliti tertarik untuk mengadakan penelitian dan membahasnya dalam sebuah laporan tugas akhir dengan judul "Efektivitas Konsumsi Tablet Fe Ditambah Jus Bayam Hijau Dan Madu Terhadap Peningkatan Kadar $\mathrm{Hb}$ Ibu".

Berdasarkan survey awal yang peneliti lakukan terhadap 10 orang ibu hamil, 7 orang dari ibu hamil tersebut mengalami anemia, 4 orang mengalami anemia ringan, 2 orang anemia sedang dan 1 orang mengalami anemia berat serta 3 orang ibu hamil lainnya tidak mengalami anemia dengan kadar $\mathrm{Hb}$ diatas $12 \mathrm{gr} / \mathrm{dl}$. Berdasarkan hasil wawancara ibu hamil yang anemia tersebut hanya 
mengkonsumsi tablet $\mathrm{Fe}$ untuk mengatasi anemianya dan tidak ada mengkonsumsi makanan khusus untuk mengatasi anemia yang sedang di alami serta ibu hamil kurang mau mengkonsumsi sayur pada saat hamil dan ada juga yang tidak mau mengkonsumsi sayur selama kehamilan.

\section{METODE PENELITIAN}

Penelitian ini merupakan jenis penelitian eksperimen yaitu pretest and posttestwith controlgroup dengan desain eksperimen semu (Quasi experimental designs). Dalam penelitian ini observasi dilakukan sebanyak 2 kali yaitu pretest/sebelum perlakuan dan posttest/sesudah perlakuan.

Populasi dalam penelitian ini adalah seluruh ibu hamil TM II-TM III berjumlah 18 orang. Teknik pengambilan sampel menggunakan teknik purposive (nonprobality) sampling. Jumlah sampel dalam penelitian ini adalah 16 orang yang dibagi kedalam 2 kelompok yaitu 8 orang kelompok eksperimen dan 8 orang kelompok kontrol. analisa statistik yang digunakan analisa univariat dan bivariat denga menggunakan uji " $T$ " test dependent.

\section{HASIL}

\section{Analisa Univariat}

a. Rata-rata Kadar $\mathrm{Hb}$ Ibu hamil kelompok intervensi sebelum konsumsi tablet fe ditambah jus bayam hijau dan madu.

\section{Tabel 1}

\begin{tabular}{|c|c|c|c|c|c|}
\hline Kategori & $\mathbf{N}$ & Mean & $\begin{array}{c}\text { Min - } \\
\text { Max }\end{array}$ & $\begin{array}{c}\text { 95\% } \\
\text { CI }\end{array}$ & SD \\
\hline $\begin{array}{c}\text { Hb } \\
\text { Sebelum }\end{array}$ & 8 & 8,075 & $7,2-9,0$ & $\begin{array}{c}7,51 \\
-\end{array}$ & 0,667 \\
& & & & 8,63 & \\
\hline
\end{tabular}

Berdasarkan tabel 1 dapat dilihat bahwa rata-rata Kadar $\mathrm{Hb} \mathrm{Ibu}$ hamil kelompok intervensi sebelum konsumsi tablet fe ditambah jus bayam hijaudan madu adalah 8,075 dengan standar deviasi 0,667. Berdasarkan hasil estimate interval dapat disimpulkan bahwa 95\%rata-rata
Kadar $\mathrm{Hb}$ Ibu hamil kelompok intervensi sebelum konsumsi tablet fe ditambah jus bayam hijaudan madu berkisar antara 7,51 $-8,63$.

b. Rata-rata Kadar $\mathrm{Hb} \mathrm{Ibu}$ hamil kelompok intervensi sesudah konsumsi tablet fe ditambah jus bayam hijau dan madu.

\section{Tabel 2}

\begin{tabular}{|c|c|c|c|c|c|}
\hline Kategori & $\mathbf{N}$ & Mean & $\begin{array}{c}\text { Min }- \\
\text { Max }\end{array}$ & $\begin{array}{c}\text { 95\% } \\
\text { CI }\end{array}$ & SD \\
\hline $\begin{array}{c}\text { Hb } \\
\text { Sesudah }\end{array}$ & 8 & 9,838 & $\begin{array}{c}8,9- \\
11,3\end{array}$ & $\begin{array}{c}9,07 \\
-\end{array}$ & 0,916 \\
& & & & 10,6 & \\
\hline
\end{tabular}

Berdasarkan tabel 2 dapat dilihat bahwa rata-rataKadar $\mathrm{Hb} \mathrm{Ibu}$ hamil kelompok intervensi sesudah konsumsi tablet fe ditambah jus bayam hijau dan madu adalah 9,838 dengan standar deviasi 0,916 . Berdasarkan hasil estimate interval dapat disimpulkan bahwa 95\%rata-rata Kadar $\mathrm{Hb}$ Ibu hamil kelompok intervensi sesudah konsumsi tablet fe ditambah jus bayam hijaudan madu berkisar antara 9,07 $-10,6$.

c. Rata-rata Kadar $\mathrm{Hb}$ Ibu hamil kelompok Kontrol sebelum konsumsi tablet fe ditambah jus bayam hijau dan madu.

\section{Tabel 3}

\begin{tabular}{|c|c|c|c|c|c|}
\hline Kategori & $\mathbf{N}$ & Mean & $\begin{array}{c}\text { Min }- \\
\text { Max }\end{array}$ & $\begin{array}{c}\mathbf{9 5 \%} \\
\text { CI }\end{array}$ & SD \\
\hline $\begin{array}{c}\text { Hb } \\
\text { Sebelum }\end{array}$ & 8 & 8,438 & $\begin{array}{c}7,7- \\
9,0\end{array}$ & $\begin{array}{c}8,07 \\
-\end{array}$ & 0,437 \\
& & & & 8,8 & \\
\hline
\end{tabular}

Berdasarkan tabel 3 dapat dilihat bahwa rata-rataKadar $\mathrm{Hb} \mathrm{Ibu}$ hamil kelompok kontrol sebelum konsumsi tablet fe ditambah jus bayam hijau dan madu adalah 8,438 dengan standar deviasi 0,437. Berdasarkan hasil estimate interval dapat disimpulkan bahwa 95\%rata-rata Kadar $\mathrm{Hb}$ Ibu hamil kelompok kontrol sebelum 
konsumsi tablet fe ditambah jus bayam hijaudan madu berkisar antara 8,07-8,8.

d. Rata-rata Kadar $\mathrm{Hb}$ Ibu hamil kelompok Kontrol sesudah konsumsi tablet fe ditambah jus bayam hijau dan madu

\section{Tabel 4}

\begin{tabular}{|c|c|c|c|c|c|}
\hline Kategori & $\mathbf{N}$ & Mean & $\begin{array}{c}\text { Min }- \\
\text { Max }\end{array}$ & $\begin{array}{c}\mathbf{9 5 \%} \\
\text { CI }\end{array}$ & SD \\
\hline $\begin{array}{c}\text { Hb } \\
\text { Sesudah }\end{array}$ & 8 & 8,588 & $7,8-9,3$ & $\begin{array}{c}8,16 \\
-\end{array}$ & 0,505 \\
& & & & 9,01 & \\
\hline
\end{tabular}

Berdasarkan tabel 4 dapat dilihat bahwa rata-rata Kadar $\mathrm{Hb}$ Ibu hamil kelompok kontrol sesudah konsumsi tablet fe ditambah jus bayam hijaudan madu adalah 8,588 dengan standar deviasi 0,505. Berdasarkan hasil estimate interval dapat disimpulkan bahwa 95\%rata-rata Kadar $\mathrm{Hb}$ Ibu hamil kelompok kontrol sesudah konsumsi tablet fe ditambah jus bayam hijaudan madu berkisar antara 8,16-9,01.

\section{Analisa Bivariat}

a. Efektivitas Konsumsi Tablet Fe Ditambah Jus Bayam Hijau Dan Madu Terhadap Peningkatan Kadar $\mathrm{Hb}$ Ibu Hamil TM II - TM III.

\section{Tabel 5}

\begin{tabular}{|c|c|c|c|c|c|}
\hline Kategori & N & $\begin{array}{c}\text { Mea } \\
\mathbf{n}\end{array}$ & $\begin{array}{c}\text { Selisih } \\
\text { Mean }\end{array}$ & SD & $\begin{array}{c}\text { P } \\
\text { Value }\end{array}$ \\
\hline Sebelum & 8 & 8,075 & 1,762 & 0,667 & \\
\cline { 1 - 1 } Setelah & 8 & 9,837 & & 0,916 & 0,000 \\
\hline
\end{tabular}

Berdasarkan tabel 5 diatas terdapat Efektivitas Konsumsi Tablet Fe Ditambah Jus Bayam HijauDan Madu Terhadap Peningkatan Kadar Hb Ibu Hamil TM II TM III. Hasil uji statistik menunjukkan terjadinya peningkatan kadar $\mathrm{Hb}$ sesudah konsumsi Tablet Fe Ditambah Jus Bayam Hijau Dan Madu dengan selisih nilai mean 1,762 dan hasil uji statistik juga didapatkan nilai $\mathrm{p}$ value $=0,000(\mathrm{p}<0,05)$, maka dapat disimpulkan terdapat
Efektivitas Konsumsi Tablet Fe Ditambah Jus Bayam HijauDan Madu Terhadap Peningkatan Kadar Hb Ibu Hamil TM II TM III.

Setiap 100 gram bayam terkandung 2,3 gram protein, 3,2 gram karbohidrat, 3 gram besi dan 81 gram kalsium. Bayam juga kaya akan berbagai macam vitamin dan mineral yakni vitamin $\mathrm{A}$, vitamin $\mathrm{C}$, niasin , thiamine, fosfor, ribovalfin, natrium , kalium dan magnesium (Yunaifi, 2013).

Bayam hijau memiliki manfaat baik bagi tubuh karena merupakan sumber kalsium, Vitamin A, Vitamin E dan Vitamin C, serat dan juga betakaroten. Selain itu bayam juga memiliki kandungan zat besi yang tinggi untuk mencegah anemia. Kandungan mineral dalam bayam cukup tinggi terutama $\mathrm{Fe}$ yang dapat digunakan untuk mencegah kelelahan akibat anemia. Karena kandungan $\mathrm{Fe}$ dalam bayam cukup tinggi, ditambah kandungan vitamin $\mathrm{B}$ terutama asam folat (Rukamana, 2006).

Peneliti berasumsi bahwa, dalam penelitian ini didapatkan nilai $p$ value $=0,000$, maka dapat disimpulkan terdapat Efektivitas Konsumsi Tablet Fe Ditambah Jus Bayam Hijau Dan Madu Terhadap Peningkatan Kadar $\mathrm{Hb}$ Ibu Hamil TM II - TM III. Setelah dilakukan uji laboratium di STIKes Fort De Kock Bukittinggi terhadap 200 gr bayam +4 sdm madu + gula dalam $200 \mathrm{~mL}$ Aquadest didapatkan kandungan $\mathrm{Fe}$ bayam dan madu yaitu 102,245 gr. Dari hasil uji laboratorium tersebut dapat kita lihat bahwa bayam dan madu mengandung zat besi yang cukup tinggi sehingga efektif membantu dalam meningkatkan kadar $\mathrm{Hb}$ ibu. 
b. Perbedaan Kadar Hb Ibu Hamil Pada Kelompok Intervensi Dan Kelompok Kontrol Sebelum Dan Sesudah Konsumsi Tablet Fe Ditambah Jus Bayam Hijau Dan Madu.

\section{Tabel 6}

\begin{tabular}{|c|c|c|c|c|c|}
\hline Kategori & $\mathbf{N}$ & $\begin{array}{c}\text { Mea } \\
\mathbf{n}\end{array}$ & $\begin{array}{c}\text { Selisih } \\
\text { Mean }\end{array}$ & SD & $\begin{array}{c}\text { P } \\
\text { Value }\end{array}$ \\
\hline $\begin{array}{c}\text { Interven } \\
\text { si }\end{array}$ & 8 & 9,838 & 1,25 & 0,916 & \multirow{2}{*}{0,012} \\
\cline { 1 - 1 } Kontrol & 8 & 8,588 & & 0,505 & \\
& & & & & \\
\hline
\end{tabular}

Berdasarkan tabel 6 diatas terdapat perbedaan kadar $\mathrm{Hb}$ ibu hamil pada kelompok intervensi dan kelompok kontrol sebelum dan sesudah konsumsi tablet fe ditambah jus bayam hijaudan madu. Hasil uji statistik didapatkan nilai $\mathrm{p}$ value $=0,012$ $(\mathrm{p}<0,05)$ dengan selisih perbandingan nilai mean kelompok intervensi dan kelompok kontrol yaitu 1,25, maka dapat disimpulkan terdapat perbedaan kadar $\mathrm{Hb}$ ibu hamil pada kelompok intervensi dan kelompok kontrol sebelum dan sesudah konsumsi tablet fe ditambah jus bayam hijaudan madu.

Hasil penelitian ini didukung oleh penelitian lain yang dilakukan oleh Anggraini, dkk (2014), dari hasil penelitian nya dinyatakan bahwa ada perbedaan kadar hemoglobin kelompok intervensi dan kelompok control dengan nilai $\mathrm{p}$ value $=0,001$. Selanjutnya penelitian ini juga sejalan dengan penelitian yang dilakukan oleh Nuraysih (2015) yang menyatakan bahwa terapi kombinasi jus bayam - jeruk - sankis- madu efektif untuk meningkatkan kadar haemoglobin pada ibu hamil dengan anemia dengan $\mathrm{p}$ value $=0,018$.

Penelitian Romatika \& Umarianti (2017) juga menyatakan bahwa Uji laboratorium pengukuran kandungan zat besi pada ekstrak bayam hijau bahwa bayam hijau segar memiliki kadar Fe 8,3 $\mathrm{mg} / 100$ gram bayam segar, hasil proses ektraksi 3.500 gram serbuk bayam hijau kering dengan $14000 \mathrm{ml}$ aquadest menghasilkan kandungan $\mathrm{Fe} 21 \mathrm{mg} / \mathrm{gr}$.

Peneliti berasumsi bahwa, dalam penelitian ini terdapat perbedaan antara kelompok intervensi dan kelompok kontrol dengan $\mathrm{p}$ value 0,012. Peneliti menyimpulkan bahwa pada kelompok kontrol tidak terlihat adanya peningkatan kadar $\mathrm{Hb}$ yang relative tinggi, hal dikarenakan pada kelompok kontrol memang tidak diberikan perlakuan berupa jus bayam hijau dan madu. Sedangkan pada kelompok intervensi terjadi peningkatan kadar $\mathrm{Hb}$ dan pada kelompok intervensi juga dinyatakan bahwa jus bayam hijau dan madu efektif meningkatkan kadar $\mathrm{Hb}$ ibu. Dalam perbedaan antara kelompok kontrol dan intervensi dalam penelitian ini dapat terlihat bahwa jus bayam hijau dan madu tersebut memang kaya kandungan zat besi dan dapat meningkatkan kadar $\mathrm{Hb}$ ibu.

\section{SIMPULAN}

Berdasarkan hasil penelitian yang berjudul "Efektivitas Konsumsi Tablet Fe Ditambah Jus Bayam Hijau Dan Madu Terhadap Peningkatan Kadar $\mathrm{Hb}$ Ibu Hamil TM II - TM III" dengan jumlah sampel sebanyak 16 orang yang dibagi dalam 2 kelompok yaitu 8 orang pada kelompok intervensi dan 8 orang pada kelompok kontrol, maka dapat disimpulkan bahwaterdapat Efektivitas Konsumsi Tablet Fe Ditambah Jus Bayam Hijau Dan Madu Terhadap Peningkatan Kadar Hb Ibu Hamil TM II - TM III dengan nilai $p$ value $=0,000$. Terdapat perbedaan kadar $\mathrm{Hb}$ ibu hamil pada kelompok intervensi dan kelompok kontrol sebelum dan sesudah konsumsi tablet fe 
ditambah jus bayam hijau dan madu dengan nilai $\mathrm{p}$ value $=0,012$.

\section{UCAPAN TERIMA KASIH}

Terima kasih pada responden yang telah ikut berpartisipasi dalam melakukan penelitian ini. Selanjutnya, terima kasih kepada bagian Laboratorium STIKes Fort De Kock sebagai tempat uji kadar bayam hijau.

\section{REFERENSI}

Aden, R. 2010. Manfaat Dan Khasiat Madu. Yogyakarta : Hanggar Kreatif Anggraeni, dkk. 2014. Pengaruh Suplemen Bayam Terhadap Perubahan Kadar Hemoglobin Laboratorium Mencit. Naskah Publikasi

Arisandi, Andriani. 2012. Therapy Herbal Pengobatan Berbagai Penyakit. Jakarta : Eska Media

Dewi Prima. 2008. Rahasia Kehamilan. Yogyakarta : Shira Medika

Dinkes. 2017. Dinas Kesehatan Kabupaten Merangin. Merangin

Dinkes. 2015. Dinas Kesehatan Provinsi Jambi. Jambi

Dutton, dkk. 2012. Rujukan Cepat Kebidanan. Jakarta : EGC

Handayani, W. dkk. 2008. Asuhan Keperawatan Pada Klien Dengan Gangguan Hematologi. Jakarta : Salemba Medika

Hidayat, A.Z. 2011. Metode Penelitian Kebidanan Dan Teknik Analisa Data. Jakarta : Salemba Medika

Hutahaean, Serri. 2013. Perawatan Antenatal. Jakarta : Salemba Medika

Lanny Lingga. 2010. Cerdas Memilih Sayuran. Jakarta : PT Agromedia Pustaka

Maria, Ana. 2008. Bertahan Hidup Dengan Terapi Jus. Yogyakarta : Pustaka Anggrek

Mandriwati, G.A. 2012. Asuhan Kebidanan Antenatal. Yogyakarta : Nuha Medika
Manuaba SpOG. 2012. Ilmu Kebidanan Penyakit Kandungan \& Keluarga Berencana Untuk Pendidkan Bidan. Jakarta : EGC

Merida Novie, dkk. 2014. Efektivitas Terapi Kombinasi Jus Bayam Dan Tomat Terhadap Peningkatan Kadar Hemoglobin Pada Ibu Hamil Dengan Anemia. Naskah Publikasi

Nanda Nic-Noc. 2013. Aplikasi Asuhan Keperawatan Berdasarkan Diagnosa Medis NANDA. Yogyakarta : Nuha Medika

Notoatmodjo Soekidjo. 2012. Metodologi Penelitian Kesehatan. Jakarta : Rineka Cipta

Nugroho, Taufan. 2010. Kamus Pintar Kesehatam Kedokteran, Keperawatan Dan Kebidanan. Yogyakarta : Nuha Medika

Nuraysih. 2015. Efektivitas Terapi Kombinasi Jus Bayam Jeruk Sunkis Madu Terhadap Kadar Hemoglobin Pada Ibu Hamil Dengan Anemia Di Wilayah Kerja UPTD Puskesmas Kecamatan Pontianak Selatan. Naskah Publikasi

Profil. 2014. Profil Kesehatan Indonesia. Indonesia

Profil. 2015. Profil Kesehatan Indonesia. Indonesia

Pujiningsih, Sri. 2010. Permasalahan Kehamilan Yang Sering Terjadi. Jakarta : PT Suka Buku

Purnawijayanti. 2009. Mie Sehat (Cara Pembuatan, Resep-Resep Olahan Dan Peluang Bisnis). yogyakarta: Kanisius

Rahmawati, Nur. Eni. 2013. Ilmu Praktis Kebidanan. Jakarta : Salemba Medika

Rohmatika \& Umarianti. 2017. Efektivitas Pemberian Ekstrak Bayam Terhadap Peningkatan Kadar Hemoglobin Pada Ibu Hamil Dengan Anemia Ringan. Naskah Publikasi

Riskesdas. 2013. Riset Kesehatan Dasar . Indonesia 
Rukamana, Ade. 2006. Pengelolaan Kelasa Dan Berbagai Faktor Mempengaruhi. Jakarta : Remaja

Rukiyah, Ai Yeyeh. 2010. Asuhan Kebidanan Patologi Kebidanan. Jakarta : Salemba Medika

Rusilanti. 2006. Menu Bergizi Untuk Ibu Hamil. Jakarta : Kawan Pustaka

Sinsin, Lis. 2009. Masa Kehamilan dan persalinan. Jakarta : EGC

Siti Fatimah. 2009. Studi Kadar Klorofil Dan Zat Besi (Fe) Pada Beberapa Jenis Bayam Terhadap Jumlah Eritrosit Tikus Putih Anemia. Naskah Publikasi

Sugiarti. 2014. Pengaruh Konsumsi Jus Bayam Merah Dan Madu Terhadap Peningkatan Kadar Hemoglobin Ibu Hamil. Naskah Publikasi

Sudewo Bambang. 2009. Buku Pintar Hidup Sehat Cara Mas Dewo.Jakarta : AgroMedia Pustaka
Sukarni K \& Margareth ZH. 2013. Kehamilan Persalinan Dan Nifas. Yogyakarta : Nuha Medika

Supariasa, dkk. 2016. Penilaian Status Gizi. Jakarta : EGC

Susiloningtyas Is. 2009. Pemberan Besi (Fe) Dalam Kehamilan. Naskah Publikasi

Swarjana. 2015. Metodologi Penelitian Kesehatan [ Edisi Revisi]. Yogyakarta : Andi

Widhi Astuti. 2013. Pengaruh mengkonsumsi jus bayam merah terhadap peningkatan kadar $\mathrm{Hb}$ pada ibu hamil di Kecamatan Tawangmangu. Naskah Publikasi

Wijojo M. 2008. Sehat Dengan Tanaman Obat. Jakarta : Bee Media Indonesia Yunaifi sadjali. 2013. Sukses Bertanam Bayam. Jakarta : ARC Media 